\title{
The perception of geography in school and society
}

Authors' Contribution: A Study Design B Data Collection

C Statistical Analysis

D Data Interpretation

E Manuscript Preparation

F Literature Search

G Funds Collection

\author{
Grigore Vasile Herman ${ }^{1}$ ADE, Mihaela Simona Biriș ${ }^{2}$ BC, Dorina Camelia Ilieș ${ }^{1}$ ADE, \\ Tudor Caciora $^{2}$ BC, Alexandru Ilies ${ }^{1}$ ADF, Jan A. Wendt ${ }^{1,3}$ ADF, Daniela Sopota ${ }^{2}$ BC \\ ${ }^{1}$ Department of Geography, Tourism and Territorial Planning, \\ University of Oradea, Oradea, Romania \\ 2 Doctoral School in Geography, University of Oradea, Oradea, Romania \\ 3 Institute of Geography, Faculty of Oceanography and Geography, \\ University of Gdansk, Gdansk, Poland
}

\section{abstract}

Background: The profound changes that the Romanian society has experienced, at the background of its transition to an information and knowledge-based society, have imposed new directions and perspectives in the field of study of Geography at school and in the society. In this context, the present study aims to know the perception of the student-teacher-parent triad regarding the role of Geography at school and in the society.

Material and methods: Using the method of questionnaire, a number of 927 participants were consulted, of which 421 were students, 357 teachers and 149 parents from Bihor county, Romania.

Results: The research focused on three basic pillars that targeted the role and importance of Geography for society, Geography in the current education system and the perception of Geography, from the perspective of career success.

Conclusions: The role of geography at school and in the society is known to the respondents. However, the current education system gives it a small importance in the instructional-educational training with repercussions on the perception of the usefulness of geography in the labor market.

Key words: geography, labor market insertion, education system.

\section{article details}

Article statistics: Word count: 3,170; Tables: 1; Figures: 1; References: 30

Received: June 2020; Accepted: August 2020; Published: November 2020

Full-text PDF: http://www.balticsportscience.com

Copyright @ Gdansk University of Physical Education and Sport, Poland

Indexation: Celdes, Clarivate Analytics Emerging Sources Citation Index (ESCI), CNKI Scholar (China National Knowledge Infrastructure), CNPIEC, De Gruyter - IBR (International Bibliography of Reviews of Scholarly Literature in the Humanities and Social Sciences), De Gruyter - IBZ (International Bibliography of Periodical Literature in the Humanities and Social Sciences), DOAJ, EBSCO - Central \& Eastern European Academic Source, EBSCO - SPORTDiscus, EBSCO Discovery Service, Google Scholar, Index Copernicus, J-Gate, Naviga (Softweco, Primo Central (ExLibris), ProQuest - Family Health, ProQuest - Health \& Medical Complete, ProQuest - Illustrata: Health Sciences, ProQuest - Nursing \& Allied Health Source, Summon (Serials Solutions/ProQuest, TDOne (TDNet), Ulrich's Periodicals Directory/ulrichsweb, WorldCat (OCLC)

Funding: This research received no specific grant from any funding agency in the public, commercial, or not-for-profit sectors.

Conflict of interests:

Corresponding author:

Open Access License:
Authors have declared that no competing interest exists.

Grigore Vasile Herman, Faculty of Geography, Tourism and Sport University of Oradea 1st University Street, 410 087 Oradea: Romaniał e-mail: grigoreherman@yahoo.com.

This is an open access article distributed under the terms of the Creative Commons Attribution-Non-Commercial-NoDerivatives 4.0 International (https://creativecommons.org/licenses/by-nc-nd/4.0/), which permits use, distribution and reproduction in any medium, provided the original work is properly cited, the use is non-commercial and is otherwise in compliance with the license. 


\section{INTRODUCTION}

The need of knowing, understanding and spatially organizing the territory even since the ancient times has led to the imposition of an occupation that aimed at "describing the land". Geography as a science was born out of a social necessity covering a series of needs, such as orientation in space, territorial delimitation, organization of the space in order to increase agricultural productivity, political and military purposes, etc. Nowadays, more than ever, the need for services offered by Geography in society is becoming more acute. The increasing number of population and the anthropogenic impact on the environment [1-7], together with technical and technological progress, as well as the aspirations of the present generations, demand efforts from Geography in order to cover them. This explains the increasing number of niche disciplines with a geographical specificity (which have become detached and evolved from Geography), which fulfill the needs of the current society. Lately, all over the world, including Romania, Geography as a field of study, and an opportunity of insertion on the labor market is in decline, its place being taken by the niche disciplines (Geology, Geomorphology, Climatology, Meteorology, Phytocoenology, Economic Geography, Political Geography, Population Geography, Topography, Cartography, Photogrammetry, Geomatics, Geostatistics, etc.), with a narrow and specialized research field. The social problems that humanity is facing nowadays can revive Geography in school and society, it being a synthetic, integrative and global science, capable of providing the right solutions.

Geography has been regarded throughout the curriculum as a discipline of encyclopaedism, but this does not correspond to the current reality because it is becoming one of the most dynamic scientific fields, with great adaptability to the increasingly accentuated changes that characterize the contemporary world [8]. The curriculum of teaching Geography in Romania has undergone multiple changes, mainly due to the changes of the forms of the country's government: from the socialist republic (before 1989) to a semi-independent one (after 1989, until now), as well as due to the accession to the European Union in 2007 [9, 10]. If, in socialism, the teaching of Geography was static, descriptive and overtheoreticized, based on the transmission of a large amount of information [11], now, after multiple reforms of the educational system, emphasis is placed on logical and creative thinking and on understanding of the relationships between Geography and other fields of study. All these induced changes in the teaching-learning process are in accordance with the needs of a constantly changing society and the new demands that have appeared on the labor market [12-14].

The quality of the learning process of Geography in the Romanian school resides in the typology and the way of transmitting information, both at secondary and high school level. Thus, if in secondary school, students are provided with general information about the Earth as a planet, the Physical Geography of Romania, the Geography of Europe and the Geography of the Continents, in high school topics are discussed from the sphere of Political Geography, population and settlements, social and cultural etc. The key competence areas from the current Geography teaching curriculum focus on communication both in mother tongue and in foreign languages, on basic competences in science and technology, on digital skills, on social and civic competences, as well as on the development of learning skills, initiative and cultural expression [15]. All these objectives individualize Geography in the Romanian contemporary school as an object of study less focused on the transmission and retention of a large amount of information, and more concerned about the development of logical, connected, spatial thinking and about the development of indispensable skills in modern society. Although it is a science whose importance for society makes it an indispensable school subject [16], in recent years, Geography is losing more ground to other disciplines. Therefore, the number of hours assigned for Geography in high school has decreased in the period after 2000 to one or two hours per week, and to one hour 
per week from 2017. For the lower cycle of high school (9th-10th grades), the current framework plan provides two hours per week for the theoretical branch, humanistic profile, respectively one hour per week for the real profile of the same branch. For the theoretical branch of the upper cycle of high school (11th-12th grades) Geography lessons are provided in the following way: one hour per week in the common trunk for humanistic profile-Philology specialization, two hours per week for humanistic profile-Social Sciences specialization and one more hour in the differentiated curriculum. The theoretical branch, real profile remains with one hour per week in the common trunk. Things seem to be different in other states of Europe, where the role of geography in school is perceived as increasingly important. For example in Poland, where after an educational reform that was not favorable to the geography, implemented in 1999, when the number of hours allocated to this discipline was reduced drastically, especially in primary and secondary schools; another reform of 2017 changed this system by increasing the number of hours of didactics of geography in both primary and secondary schools.

In Romania, geography was also eliminated from the list of compulsory school subjects for the examination that takes place at the end of the gymnasium cycle; it is also missing from the examination disciplines at the National Assessments that takes place at the end of the 6th grade and it remains an optional subject that can be chosen at the Baccalaureate Exam only for the humanistic and vocational profile [17]. As for Poland, the popularity of geography among students is suggested by the fact that that it is in the group of the three most frequently chosen additional subjects at the matriculation exams in most examination committees in the country. On the one hand, it may be a result of recognizing it as an easier subject than physics, biology, chemistry or history. On the other hand, the topics of the school subject, always interesting for young people, make students choose geography at the final exams, in truth, colloquially and mistakenly identified with travel, tourism, exploring and curiosity in the modern world. However, this curiosity is a trait of humanity who has discovered and is discovering the world in various aspects [18-21].

The perception of geography as an important subject in contemporary teaching seems to be underestimated. Many factors contributed to the high status of geography as a subject in education in primary, junior high and high schools. It seems that the most important of them is the problem that geography or rather the geographical sciences have on their own. The former paradigm of descriptive world teaching in the internet age is completely outdated. New, holistic teaching about the environment, at the pre-university stage is still under development. In the context of the current educational system which is not at all favorable to "Geography" as a field of study, the knowledge of its perception at the level of the educational triad (teacher-student-parent) represents a sine-qua-non desire, in figuring out the mechanisms that contribute to the perception of Geography in school and society.

Therefore, the purpose of this study is to know the perception of geography in school and society, as a discipline of study and science in terms of their usefulness. The hypothesis from which this approach was taken concerns the unfavorable context of geography as a discipline of study in school, on the one hand, and its importance as a science for society and the environment, on the other hand, at the background of intensifying anthropogenic impact and manifesting its devastating effects in some situations. This approach involved consulting (in order to know the perception of the role of geography in school and society) a representative sample of 927 respondents representing the school (421 students and 357 teachers) and the society (149 parents, as the key players in society). 


\section{MATERIAL AND METHODS}

The data needed to carry out the present study were obtained between December 2019January 2020, in Oradea, Bihor County, Romania using the questionnaire-based sociological survey method [22-28]. The methodology that was used involved consulting the participants (students, parents and teachers), through the method of online questionnaire regarding "the perception of the role of Geography in school and society" which was available at the following link https://docs.google.com/forms/d/1nE7C4taMPzAtotWzzpnkYNgEOSDvG-3 R4SaQKfDsN4/edit.

Structurally, the questionnaire focused on six items (three with a closed answer, two with a mixed answer and one with an open answer) with reference to: the degree of knowledge of the role and importance of Geography for the society; the importance of Geography as a field of study in the current education system; the number of Geography hours per week in the curriculum; the perception of ensuring a successful career through the study of Geography; the fields of insertion of Geography graduates on the labor market and the necessary measures to improve the perception regarding Geography. Within the questionnaire there were also captured socio-demographic data such as gender, age, area of residence and ethnicity.

\section{RESULTS}

Information regarding the perception of the role of Geography in school and society was obtained by consulting a number of 927 participants: student's representatives (421 people, $45 \%$ ), teachers (357 people, 39\%) and parents (149 people, 16\%). In the shaping of the respondents' socio-demographic profile the following analytical aspects were targeted: gender, age, residence and ethnicity. There were 508 (54.8\%) female participants and 419 $(45.2 \%)$ male participants, between the ages of 12 and 64 years.

Regarding the respondents' age, it was found that the largest share of them was held by the group of mature participants, aged between $20-60$ years, 55.7\% (516 participants), followed by the group of young people, between the ages of $12-19$ years, $43.8 \%$ (406 participants) and lastly the elderly ones, over 60 years old, $0.6 \%$ (6 participants). Regarding the participants' residence, 736 participants (79.4\%) were from urban areas and the rest of 191 participants (20.6\%) were from rural areas. From an ethnical point of view, the Romanians predominated with $96.2 \%$ (Table 1 ).

Table 1. The participants' answers to the questionnaire regarding the perception of Geography in school and society

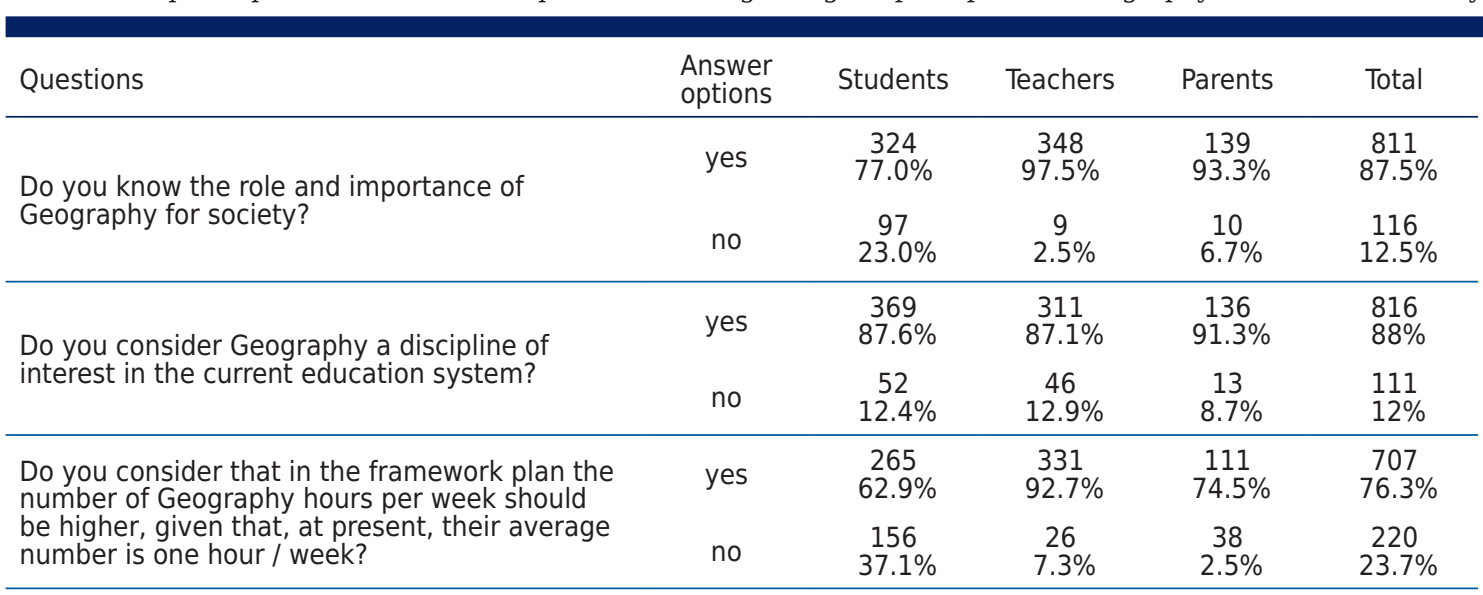




\begin{tabular}{|c|c|c|c|c|c|}
\hline Questions & $\begin{array}{l}\text { Answer } \\
\text { options }\end{array}$ & Students & Teachers & Parents & Total \\
\hline \multirow{10}{*}{$\begin{array}{l}\text { To what extent can studying Geography ensure } \\
\text { you a successful career? }\end{array}$} & 1 & $\begin{array}{l}14 \\
3.3 \%\end{array}$ & $2.99 \%$ & $\begin{array}{l}3 \\
2 \%\end{array}$ & $2.8 \%$ \\
\hline & 2 & $2.6 \%$ & $\stackrel{4}{1.1 \%}$ & $\begin{array}{l}0 \\
0 \%\end{array}$ & $\begin{array}{l}15 \\
1.6 \%\end{array}$ \\
\hline & 3 & $\begin{array}{l}20 \\
4.8 \%\end{array}$ & $\begin{array}{l}5 \\
1.4 \%\end{array}$ & $0.7 \%$ & $2.8 \%$ \\
\hline & 4 & $\begin{array}{l}30 \\
7.1 \%\end{array}$ & $\begin{array}{l}3 \\
0.8 \%\end{array}$ & $\begin{array}{l}5 \\
3.4 \%\end{array}$ & $\begin{array}{l}38 \\
4.1 \%\end{array}$ \\
\hline & 5 & $\begin{array}{l}56 \\
13.3 \%\end{array}$ & $\begin{array}{l}6 \\
1.7 \%\end{array}$ & $\begin{array}{c}9 \\
6 \%\end{array}$ & $\begin{array}{l}71 \\
7.7 \%\end{array}$ \\
\hline & 6 & $\begin{array}{c}45 \\
10.7 \%\end{array}$ & $\begin{array}{l}7 \\
2 \%\end{array}$ & $\begin{array}{l}6 \\
4 \%\end{array}$ & $\begin{array}{l}58 \\
6.3 \%\end{array}$ \\
\hline & 7 & $\begin{array}{c}73 \\
17.3 \%\end{array}$ & $\begin{array}{l}14 \\
3.9 \%\end{array}$ & $\begin{array}{l}24 \\
16.1 \%\end{array}$ & $\begin{array}{l}111 \\
12 \%\end{array}$ \\
\hline & 8 & $\begin{array}{c}75 \\
17.8 \%\end{array}$ & $\begin{array}{l}59 \\
16.5 \%\end{array}$ & $\begin{array}{ll}26 \\
17.4 \%\end{array}$ & $\begin{array}{l}160 \\
17.3 \%\end{array}$ \\
\hline & 9 & $\begin{array}{l}47 \\
11.2 \%\end{array}$ & $\begin{array}{c}74 \\
20.7 \%\end{array}$ & $22.1 \%$ & $\begin{array}{l}154 \\
16.6 \%\end{array}$ \\
\hline & 10 & $\begin{array}{l}50 \\
11.9 \% \\
\end{array}$ & $\begin{array}{l}176 \\
49.3 \%\end{array}$ & $\begin{array}{c}42 \\
28.2 \%\end{array}$ & $\begin{array}{c}268 \\
28.9 \% \\
\end{array}$ \\
\hline \multirow{2}{*}{$\begin{array}{l}\text { Do you know the areas of insertion of } \\
\text { Geography graduates on the labor market? }\end{array}$} & yes & $\begin{array}{c}131 \\
31.1 \%\end{array}$ & $\begin{array}{c}292 \\
81.8 \%\end{array}$ & $\begin{array}{c}91 \\
61.1 \%\end{array}$ & $\begin{array}{c}514 \\
55.4 \%\end{array}$ \\
\hline & no & $\begin{array}{l}290 \\
68.9 \%\end{array}$ & $\begin{array}{c}65 \\
18.2 \% \\
\end{array}$ & $\begin{array}{l}58 \\
38.9 \% \\
\end{array}$ & $\begin{array}{c}413 \\
44.6 \% \\
\end{array}$ \\
\hline \multirow{2}{*}{ Gender } & $M$ & $\begin{array}{l}270 \\
64 \%\end{array}$ & $\begin{array}{l}102 \\
28.6 \%\end{array}$ & $\begin{array}{l}47 \\
31.5 \%\end{array}$ & $\begin{array}{l}419 \\
45.2 \%\end{array}$ \\
\hline & $\mathrm{F}$ & $\begin{array}{l}151 \\
35.9 \% \\
\end{array}$ & $\begin{array}{l}255 \\
71.4 \% \\
\end{array}$ & $\begin{array}{c}102 \\
68.5 \% \\
\end{array}$ & $\begin{array}{c}508 \\
54.8 \% \\
\end{array}$ \\
\hline \multirow{2}{*}{ Residence } & rural & $\begin{array}{c}89 \\
21.1 \%\end{array}$ & $\begin{array}{c}80 \\
22.4 \%\end{array}$ & $\begin{array}{c}22 \\
14.8 \%\end{array}$ & $\begin{array}{c}191 \\
20.6 \%\end{array}$ \\
\hline & urban & $\begin{array}{c}332 \\
78.9 \% \\
\end{array}$ & $\begin{array}{c}277 \\
77.6 \% \\
\end{array}$ & $\begin{array}{r}127 \\
85.2 \% \\
\end{array}$ & $\begin{array}{c}736 \\
79.4 \% \\
\end{array}$ \\
\hline \multirow{4}{*}{ Ethnicity } & Romanian & $\begin{array}{l}407 \\
96.7 \%\end{array}$ & $\begin{array}{l}339 \\
95 \%\end{array}$ & $\begin{array}{l}146 \\
98 \%\end{array}$ & $\begin{array}{c}892 \\
96.2 \%\end{array}$ \\
\hline & Hungarian & $\begin{array}{c}6 \\
1.4 \%\end{array}$ & $\begin{array}{l}2 \\
0.6 \%\end{array}$ & $\begin{array}{c}0 \\
0 \%\end{array}$ & $\begin{array}{c}8 \\
0.9 \%\end{array}$ \\
\hline & Gipsy & $\begin{array}{c}5 \\
1.2 \%\end{array}$ & $\begin{array}{c}7 \\
2 \%\end{array}$ & $0.7 \%$ & $\begin{array}{c}13 \\
1.4 \%\end{array}$ \\
\hline & other & $\begin{array}{c}3 \\
0.7 \%\end{array}$ & $\begin{array}{c}9 \\
2.5 \% \\
\end{array}$ & $\begin{array}{c}2 \\
1.3 \% \\
\end{array}$ & $\begin{array}{c}14 \\
1.5 \% \\
\end{array}$ \\
\hline \multirow{4}{*}{ Age } & $<19$ & $\begin{array}{c}405 \\
96.2 \%\end{array}$ & $\begin{array}{c}0 \\
0 \%\end{array}$ & $0.7 \%$ & $\begin{array}{c}406 \\
43.8 \%\end{array}$ \\
\hline & $19-60$ & $\begin{array}{c}16 \\
3.8 \%\end{array}$ & $\begin{array}{c}351 \\
98.3 \%\end{array}$ & $\begin{array}{c}149 \\
100 \%\end{array}$ & $\begin{array}{c}516 \\
55.7 \%\end{array}$ \\
\hline & $>60$ & $\begin{array}{c}0 \\
0 \% \\
\end{array}$ & $\begin{array}{c}6 \\
1.7 \% \\
\end{array}$ & $\begin{array}{c}0 \\
0 \% \\
\end{array}$ & $\begin{array}{c}6 \\
0.6 \% \\
\end{array}$ \\
\hline & Total & $\begin{array}{c}421 \\
100 \%\end{array}$ & $\begin{array}{c}357 \\
100 \%\end{array}$ & $\begin{array}{c}149 \\
100 \%\end{array}$ & $\begin{array}{c}927 \\
100 \%\end{array}$ \\
\hline
\end{tabular}

\section{DISCUSSION}

\section{THE ROLE AND IMPORTANCE OF GEOGRAPHY FOR SOCIETY}

Geography has been and is a "science" that has accompanied humanity since ancient times, giving it answers and existential alternatives. Over time, humans have perceived it in different ways, their perception depending on the technical and technological progress, as well as on the level of knowledge achieved on the evolutionary scale. These differences of perception have manifested and are still manifesting nowadays, at the spatial level, among the human communities. 
The analysis of the respondents' answers to the question 1 "Do you know the role and importance of Geography for society?" highlighted the existence of a percentage of $87.5 \%$ (811 participants who answered yes, of which 348 teachers, 324 students and 139 parents) (Table 1). The arguments they offered are extremely diverse. Thus, it has been noticed that a major number of the participants consider Geography important because it contributes to the formation of the environmental skills. Being a synthesizing science that uses information from other sciences (Astronomy, Physics, Biology, Chemistry, etc.), Geography can explain the surrounding world to everybody and this way contributes to the formation/enrichment of their general cultural knowledge. Also, Geography is the science that helps us discover, understand, solve and prevent a number of fundamental problems of the world in which we live.

\section{GEOGRAPHY IN THE CURRENT EDUCATIONAL SYSTEM}

The Geography's place in the current education system is a reflection of its usefulness in the current society $[29,30]$. On the background of globalization, there is a noticeable tendency for niche specializations, by splitting the classical disciplines into sub-disciplines that deal with the study of details. In this context, Geography, which is a synthesizing and integrative science, loses ground to the detriment of niche sciences. Nevertheless, it is and it will be a useful tool for society that offers global, integrative responses that niche sciences do not have the capacity to offer.

Thus, at item 2 "Do you consider that Geography is a subject of interest in the current education system?" 88.0\%, 816 participants (369 students, 311 teachers and 136 parents), answered yes (Table 1). From the analysis of the answers offered by the participants to item 3 "Do you consider that in the framework plan the number of Geography hours per week should be higher, given that, at present, their average number is one hour / week?" it was noted that only 76.3\%, 707 participants (331 teachers, 265 students and 111 parents) considered it useful to increase the number of hours in the curricula. Regarding the need to increase the number of Geography hours per week, we can notice a major decrease among students (24\%) and parents (18.8\%) who answered positively, while the group of teachers who answered positively increased by $5.6 \%$ (Table 1 ). The explanations are closely related to the fact that Geography was eliminated from the list of compulsory subjects at the examination that takes place at the end of the junior high school cycle, was eliminated from the National Assessments and it remained an optional subject at the Baccalaureate Exam only for the humanistic and vocational profile.

\section{IHE PERCEPTION OF GEOGRAPHY FROM THE PRISM OF CAREER SUCCESS}

The usefulness of Geography for society also marks out from the opportunity to succeed in career. In this context, the participants were asked to answer item 4 "To what extent can studying Geography ensure you a successful career?" On a scale from 1 to 10 , where $1=$ Not at all, and $10=$ to a very great extent, it can be seen that $45.5 \%$ (422 participants) consider that Geography is very important (Table 1). However, the analysis of the proportion of those who consider Geography to be very important highlights the low percentage of participants from the category of students and parents (Figure 1, Table 1).

We can observe some association between the tendency of the perception of Geography's role in school (item 3, Table 1), respectively in society (item 4, Table 1) in all the categories of participants. 29.2\% (271 participants) consider that Geography is important to a great extent, while the proportion of those who consider Geography to be important to a small extent is very low $(4.4 \%, 41$ participants) (Table 1$)$.

The results obtained at item 4 can be correlated with those obtained at item 5 "Do you know the areas of insertion of Geography graduates on the labor market?". Thus, 55.4\% answered in affirmative, while only $81 \%$ of them provided information regarding this (Table 1 ). 


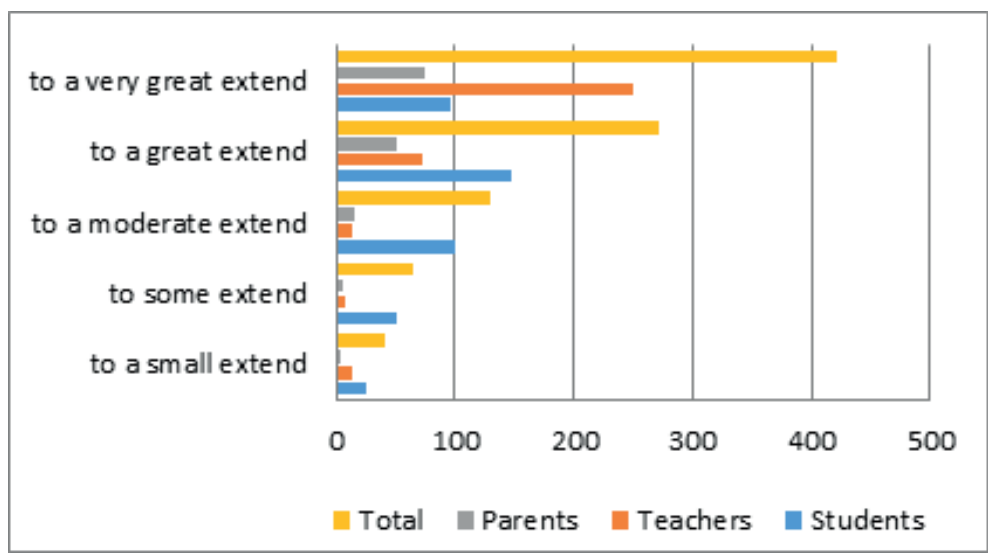

Fig.1. Assessing the extent to which the study of Geography can ensure a successful career

Analyzing the offered answers, it can be noticed that the participants consider that the study of Geography can ensure a successful career in the following fields: Education, Tourism, Environmental Protection, Meteorology, Hydrology, Urbanism, Speleology, Demographic Statistics, Research, Archeology, Seismology, Cadastre, etc.

When the participants are asked to list some measures to improve the perception regarding Geography, as a field of study, it is noted that it is desired to carry out practical and interactive activities, experiments and trips that allow teachers and students to carry out lessons in a non-formal environment.

It is also proposed that besides increasing the number of hours, to introduce this discipline as a subject of examination at the end of gymnasium or high school and to introduce it at the admission to the Universities of this profile. The opening of the selection area of the Geography graduates to different positions in the administration (technical, agricultural, urbanism) is seen as an opportunity to improve the public's perception of this field.

\section{CONCLUSIONS}

Geography, through the roles and functions it has fulfilled over time for man and society is well perceived today in the communities of Oradea, Bihor County, so $87.5 \%$ of respondents said they know the role of geography for society. However, the analysis of the data provided by the participants from from the studied area indicates that Geography, although not receiving the proper attention (in school), is considered an important discipline (88.0\%, 816 participants: 369 students, 311 teachers and 136 parents), whose knowledge, abilities and skills can be successfully used in choosing a career and in inserting on the labor market. Thus, on a scale from 1 to 10,45.5\% (422 participants) consider that Geography is very important because it offers real perspectives of insertion on the labor market (Table 1). However, it can be noticed that only $55.4 \%$ of the participants claimed that they know the areas of insertion of the Geography graduates on the labor market, while only $81 \%$ of them provided information in this regard. It appears from the presented results that the interviewed respondents perceive geography as important both in school ( $88 \%$ consider that geography is a discipline of interest in the current education system) and for society ( $87 \%$ know the role and importance of geography for society).

\section{REFERENCES}

[1] Herman GV. Omul şi modificările antropice din Câmpia Someşului [The man and anthropogenic changes in Somes Plain]. Editura Universităţii din Oradea; 2009. 
[2] Romocea T, Oneț A, Sabău NC, Oneț C, Herman GV, Pantea E. Change of the groundwater quality from Industrial Area Oradea, Romania, using Geographic Information Systems (GIS). Environ Eng Management J (EEMJ). 2018;17(9):218999. https://doi.org/10.30638/eemj.2018.217

[3] Andronache I, Marin M, Fischer R, et al. Dynamics of forest fragmentation and connectivity using particle and fractal analysis. Sci Rep. 2019;9(1):1-9. https://doi.org/10.1038/s41598-019-48277-z

[4] Herman GV, Gaceu O, Mester C, Baias S, Caciora T, Wendt JA. Spatial analysis of water quality in Natura 2000 Sites Bihor, Romania. J Environ Protect Ecology. 2019;20(4):2121-29.

[5] Herman GV, Ilies D, Gaceu O, et al. Some Considerations concerning the quality of groundwater in the Natura 2000 Lunca Barcaului (Barcaului Meadow) Site, Romania. J Environ Protect Ecology. 2019;20(3):1102-9

[6] Oneț C, Ilieș DC, Buhaș S, et al. Microbial air contamination in indoor environment of university sports hall. J Environ Protect Ecology. 2018;19(2):694-703.

[7] Ilieș DC, Buhaș R, Ilieș A, et al. Indoor air quality issue. Case study: The multipurpose sports hall of the university of Oradea. Environ Eng Management J. 2018;17(12):2999-3005. https://doi.org/10.30638/eemj.2018.300

[8] Arrowsmith C, Bagoly-Simó P, Finchum A, Oda K, Pawson E. Student employability and its implications for geography curricula and learning practices. J Geography High Educ. 2011;35(3):365-77. https://doi.org/10.1080/03098265.2011.563379

[9] Bagoly-Simó P. Tracing sustainability: Education for sustainable development in the lower secondary Geography curricula of Germany, Romania, and Mexico. Int Res Geograph Environ Educ. 2014;23(2):126-41. https://doi.org/1 $0.1080 / 10382046.2014 .908525$

[10] Butt G, Lambert D. International perspectives on the future of Geography education: an analysis of national curricula and standards. Int Res Geograph Environ Educ. 2014;23(1):1-12. https://doi.org/10.1080/10382046.2013.858402

[11] Jucu IS. Rethinking Geography in Romanian schools: curricular changes in Geography learning in post-socialist Romania, Social and Behavioral Sciences. 2012;46,5440-48. https://doi.org/10.1016/j.sbspro.2012.06.454

[12] Niță MR, Clius M, Gavrilidis AA. The impact of Geography curricula on employability: a student perspective. Romanian Review of Geographical Education. 2018;7(2):5-22. https://doi.org/10.23741/RRGE220181

[13] Solem M, Lambert D, Tani S. Geocapabilities: Toward An international framework for researching the purposes and values of geography education. Rev Int Geograph Educ. 2013;3(3);214-29.

[14] Ilieș DC, Buhaș R, Ilieș M, et al. Sport activities and leisure in Nature 2000 Protected Area - Red Valley, Romania. J Environ Protect Ecology. 2018;19(1):367-72.

[15] Mândruț O, Dan S. Geografia în curriculum național. Corint Educational, București; 2015.

[16] Bostan C. Research about Importance of Natural Sciences Given to Romanian Curriculum. Procedia - Social and Behavioral Sciences. 2013;76:110-8. https://doi.org/10.1016/j.sbspro.2013.04.083

[17] Dulamă ME, Magdaș I, Ilovan OR. Teachers' opinions on the Geography secondary school curriculum. Romanian Review of Geographical Education. 2017;6(1):5-26. https://doi.org/10.23741/RRGE120171

[18] Herman GV, Caciora T, Dumbravă R, et al. Geographical considerations regarding the tourist information and promotion centers from Bihor county, Romania. GeoJournal of Tourism and Geosites. 2019;27(4):1439-48. https:// doi.org/10.30892/gtg.27427-446

[19] Koshim AG, Sergeyeva AM, Saparov KT, Wendt JA. Development of scientific tourism at Baikonur Cosmodrome, Kazakhstan. GeoJournal of Tourism and Geosites. 2019;24 (1):267-79. https://doi.org/10.30892/gtg.24121-358

[20] Dragos P, Lucaciu G, Trifa I, Stef Gavris M, Szabo-Alexi P, Buhas S. Aspects regarding the influence of communication on the motivation of employees in some sports organisations. In Proceedings of the 4 th international conference of the universitaria consortium (ICU 2018): The impact of sport and physical education science on today society, Editografica SRL, INTL Proceedings Div, Bologna, Italy. 2018; 73-7.

[21] Dragos P, Lucaciu G, Dinis I, Stef Gavriș M, Szabo-Alexi P, Buhas S. Conceps concerning the content of childrens training in some sport games Proceedings of the 4th international conference of the universitaria consortium (ICU 2018): The impact of sport and physical education science on today society, Editografica SRL, INTL Proceedings Div, Bologna, Italy. 2018; 62-72.

[22] Bryman A. Social research methods, 4th edition. Oxford University Press, USA; 2012.

[23] Bar R, Tătar CF, Herman GV. Satisfaction degree rating of tourist services in Buziaș spa, Timiș County, Romania. GeoJournal of Tourism and Geosites. 2016;18(2):212-23.

[24] Herman GV, Wendt AJ, Dumbravă R, Gozner M. The role and importance of promotion centers in creating the image of tourist destination: Romania. Geographia Polonica. 2019;92(4):443-54. https://doi.org/10.7163/GPol.0158

[25] Ilies DC, Buhas R, Ilies A, Morar C, Herman GV. Nymphaea Lotus Var. Thermali (Pârâul Pețea Nature Reserve), brand near extinction of the Băile Felix - Băile 1 Mai (Romania) spa tourism system. GeoJournal of Tourism and Geosites. 2015;15(1):107-17.

[26] Marcu V, Buhas S. Sport organisations - management and science, Procedia - Social and Behavioral Sciences. 2014;117,678-82. https://doi.org/10.1016/j.sbspro.2014.02.281

[27] Tătar C, Herman GV, Bar R. Satisfaction degree rating of tourist services in Buziaș Spa, Timiș County, Romania. GeoJournal of Tourism and Geosites. 2016;18(2):212-23.

[28] WendtJ, Buhaș R, Herman GV. Experience of the Baile-Felix Tourist System (Romania) for the protection and promotion of the grey seal as a brend on the Hel Peninsular (Poland). Baltic Region/Baltijskij Region. 2019;11(1):109-16. https:// doi.org/10.5922/2079-8555-2019-1-8

[29] Ianoș I. Reforma curriculara si piata fortei de munca pentru domeniul Geografie. Editura Universitara Bucuresti; 2014.

[30] Ianoş I. Inserția teritorială a universităților din România. Editura Universitară, București; 2010. 